\title{
Small Intestine Cancer TNM Finding v7
}

National Cancer Institute

\section{Source}

National Cancer Institute. Small Intestine Cancer TNM Finding v7. NCI Thesaurus. Code C89862.

A finding about one or more characteristics of small intestine cancer, following the rules of the TNM AJCC v7 classification system. Lymphomas, carcinoid tumors, and visceral sarcomas are not included in this classification. (from AJCC 7th Ed.) 